Revista Brasileira de Higiene e Sanidade Animal Brazilian Journal of Hygiene and Animal Sanity ISSN: 1981-2965

\title{
The occurence of anti-Toxocara IgG to follow visceral larva migrans infections in children attended in basic health care units from peripheral areas of the city of Lages, Santa Catarina, Brazil.
}

\author{
A ocorrência de IgG anti-Toxocara no seguimento de infecções por larva migrans visceral \\ em crianças atendidas em unidades básicas de saúde de áreas periféricas da cidade de \\ Lages, Santa Catarina, Brasil.
}

\section{Rosiléia Marinho de Quadros ${ }^{1}$, Rafael de Lima Miguel ${ }^{1}$, Marina Ferrari ${ }^{1}$, Thiago Monteiro Fronza ${ }^{1}$, Luiz Claudio Miletti ${ }^{2}$, Carlos José Raupp Ramos ${ }^{3}$}

Resumo: A larva migrans visceral (LMV) é causada pela infecção de larvas de Toxocara canis, um parasita do intestino delgado, principalmente de cães, infectando humanos ocasionalmente, causando inflamação e danos a vários órgãos com sinais clínicos variando de assintomáticos a inespecíficos. $\mathrm{O}$ objetivo deste estudo foi investigar a ocorrência de anti-T. canis IgG em crianças atendidas em Unidades Básicas de Saúde do município de Lages, Santa Catarina, Brasil. Amostras de sangue de crianças foram coletadas por punção digital, armazenadas em papéis filtro e posteriormente analisadas pelo Enzymelinked Immunosorbent Assay (ELISA) para detectar anticorpos IgG contra T. canis. Os exames laboratoriais foram realizados no Laboratório de Zoologia e Parasitologia da Universidade Planalto Catarinense (UNIPLAC). A pesquisa foi realizada no período de julho de 2014 a maio de 2015, em crianças de ambos os sexos com idade entre dois e seis anos, residentes na periferia da cidade. Das 82 crianças amostradas, 43 eram meninos e 39 meninas, onde 23,17\% (19/82) tinham cinco anos de idade. Positividade para anti-T.canis IgG foi de 15,85\% (13/82), ou seja, 20,33\% de todos os meninos e 10,26\% das meninas. Embora os dados soroepidemiológicos anti-T. canis em crianças em nível nacional apresentem muitas variações, é de suma importância conhecer os dados da parasitose em diferentes regiões do Brasil, uma vez que as cidades abrigam um elevado número de cães urbanos que transitam em parques e escolas.

Palavras-chave: Toxocara canis; crianças; IgG; ELISA.

Abstract: Visceral larva migrans (VLM) is caused by Toxocara canis larvae infection, which is a small intestine parasite found mainly in dogs, infecting humans occasionally, causing inflammation and damage to several organs with clinical signs ranging from asymptomatic to nonspecific symptoms. The goal of this study was to investigate the occurrence of anti-T. canis IgG in children attended at Basic Health Care Units in the city of Lages, Santa Catarina Brazil. Children's blood samples were collected by digital puncture, stored in filter papers and later analyzed by the Enzyme-linked Immunosorbent Assay (ELISA) to detect IgG antibodies against T. canis. Laboratory tests were conducted at the Zoology and Parasitology Laboratory of the Planalto Catarinense University (UNIPLAC). The research was conducted from July 2014 to May 2015, in children of both genders aged two to six years old, residing in the peripheral area of the city. Of the 82 children sampled, 43 were boys and 39 girls where $23.17 \%(19 / 82)$ aged five years old. Positivity for anti-T. canis IgG was $15.85 \%$ (13/82), i.e., $20.33 \%$ of all boys and $10.26 \%$ of the girls. Although the seroepidemiological anti-T. canis data in children at the national level present many variations, it is of paramount importance to know the parasitosis data atdifferent regions of Brazil, since the cities harbor an elevated number of urban dogs transiting in parks and schools. 
Keywords: Toxocara canis; children; IgG; ELISA.

Endereço para correspondência; E-mail: luiz.miletti@udesc.br

Recebido em 10.1.2020. Aceito em 30.03.2020

http://dx.doi.org/10.5935/1981-2965.20200003

${ }^{1}$ Laboratório de Parasitologia e Zoologia - Universidade do Planalto Catarinense (UNIPLAC).

${ }^{2}$ Laboratório de Bioquímica de Hemoparasitas e Vetores - Universidade do estado de Santa Catarina (UDESC), Centro de Ciências Agroveterinárias - CAV / Av. Luiz de Camões, 2090 - Conta Dinheiro Lages - SC CEP: 88.520-000 / Telefone: (49) 3289-9100 - luiz.miletti@udesc.br (endereço para correspondência)

3 Laboratório de Microbiologia, Parasitologia, Ictioparasitologia e Patologia de Organismos Aquáticos Cultiváveis - Universidade Federal da Fronteira Sul (UFFS).

\section{Introduction}

The term visceral larva migrans (VLM) or human toxocariasis is an anthropozoonosis characterized by the migration of nematode Toxocara canis larvae in tissues or viscera, (MORII et al., 2015). VLM is a parasitosis with broad geographical distribution, described in all continents, more frequently present in tropical and subtropical areas (PERUCA et al., 2009). The possibility of infection is higher in children, osince they enter in contact with dog feces-contaminated soil, followed by eggs or larvae ingestion, either by geophagy, onychophagy, fomites or through contaminated hands.

Aside from children, the general population can also be infected by poorly sanitized raw vegetables (Coelho, 2001; Queiroz \& Chieffi, 2005) or by the ingestion of poorly cooked meat (LIM, 2012).

Once humans are infected, the parasite may affect many organs like the liver, lungs, kidneys, heart, striated muscle, nervous system and the eyeball (Von söhstein \& Silva, 2015).

The disease is not rare, however, its frequency is underestimated due to the difficulty of detecting the larvae in tissues and the nonspecific symptoms associated with the parasitosis (QUEIROZ \& CHIEFFI, 2005).

According to clinical and immunological symptoms, toxocariasis can be classified as classical, asymptomatic, hidden or systemically compartmentalized, which refers to the ocular and neurological forms.

The classical systemic form corresponds to the severe form of the disease characterized by the presence of respiratory symptoms such as acute to chronic pneumopathy, leukocytosis, elevated eosinophilia, fever and hepatosplenomegaly (Pedroso et al., 2015); while the asymptomatic form may be due to an old or 
mild infection, in the presence or absence of eosinophilia and being responsible for $44.4 \%$ of cases (ALTCHEH et al., 2003). The concern regarding this clinical form is due to the rapid progress to the ocular and neurological forms in children (BASS et al., 1987). The hidden phase is when the disease presents nonspecific symptoms, which disappear after treatment (PAWLOWSKI, 2001). The ocular and neurological forms affect the eyeball and the nervous system, respectively (BACHLI et al., 2004; MOREIRA-SILVA et al., 2004; GRAEFFTEIXEIRA et al., 2009), causing clinical manifestations in the retina, optical nerve, among other symptoms such as epilepsy and meningoencephalitis.

VLM diagnosis is frequently based on epidemiological studies and clinical symptoms associated with serological exams (Machado \& Achkar, 2003). The most recommended test is the enzyme immunoassay (ELISA) that is based on secreting-excreting antigens of the larval stage (SANTARÉM et al., 2009).

Given that $T$. canis is frequently transmitted by dogs and limited information regarding children infections are available, the goal of this study is to verify the occurrence of anti-T. canis IgGs in children attended at the Basic Health Care Units (BHU) of Lages, Santa Catarina.

\section{Material and methods}

For this study, blood samples were collected by digital puncture of children with ages between two to six years old, of both genders, residing in the peripheral area of the city of Lages, Santa Catarina, Brazil (Figure 1). Briefly, to collect the samples, a semiautomatic lancing device OneTouch ${ }^{\circledR}$ Ultrasoft TM along with OneTouch ${ }^{\circledR}$ Ultrasoft TM lance $\mathrm{n}^{\mathrm{o}} 28$ were used. The blood was collected by capillary puncture, which collects a mixture of artery, vein and capillary blood (MOTTA, 2009). The puncture was done on the internal palm of the distal phalanx of the middle finger. The depth of the lance puncture was adjusted on the lancing device in the position of medium puncture.

The blood samples were collected on filter papers andafter being dried, were wrapped in aluminum foil, and labeled with personal information such as address, age, and gender. Samples were stored at $8^{\circ} \mathrm{C}$ until being processed, with analysis being done within a maximum of 15 days. For processing, the samples were placed at room temperature and the blood washed with phosphate buffered saline (PBS) and 
centrifuged in individual microtubes for 10 previous studies (MOTTA, 2009).

The resulting material was submitted to the commercially available enzyme immunoassay (RIDASCREEN ${ }^{\circledR}$ Toxocara IgG, R-Biopharm, Darmstadt, Germany), following manufacturer instructions. The immunoassay is an immune enzyme test to detect secreted antibodies against $T$. canis.

This study was conducted from July 2014 through May 2015 and was approved by the Human Research Ethics Committee of the Planalto Catarinense University (UNIPLAC) $n^{\circ} 721.694$ of 2014.

\section{Results and Discussion}

Eighty-two children were sampled, being 43 boys and 39 girls. Positivity for IgG against $T$. canis was $15.85 \%$ (13/82), being $63.08 \%$ among boys and $38.46 \%$ among girls. Regarding the age of the children, 23.71\% (19/82) was five years old.

All children tested during winter $(39,02 \%)$ resulted in negative serological tests, while during summer and spring serology was positive. However, this data is only important to the period in which infection may happen and not about the minutes at 166 spins/second, according to positivity of the serological exam, since finding antibodies does not determine the infection phase.

The children involved in this study reside in 19 different neighborhoods of the city, as shown in Figure 1.

The risk of T.canis infection has increased in Brazil, mostly due to the growing number of domestic and urban dogs that wander in recreation areas (SCAINI et al., 2003; GUIMARÃES et al., 2005).

Pet estimates in Brazil are rare or nonexistent in many regions. Alves et al. (2005) declared that demographic data for dog and cat populations are fundamental for an effective public health management, especially in cases of zoonosis. The fact that dogs act as primary hosts of many zoonotic diseases has raised the concern of public health management. From an epidemiological point of view, urban dogs play an important role in the environmental contamination, since they do not receive proper antiparasitic treatments and freely inhabit public areas, facilitating the easy spread of parasites. 
Figure 1 - Distribution of the sampled children in the municipality of Lages (SC).

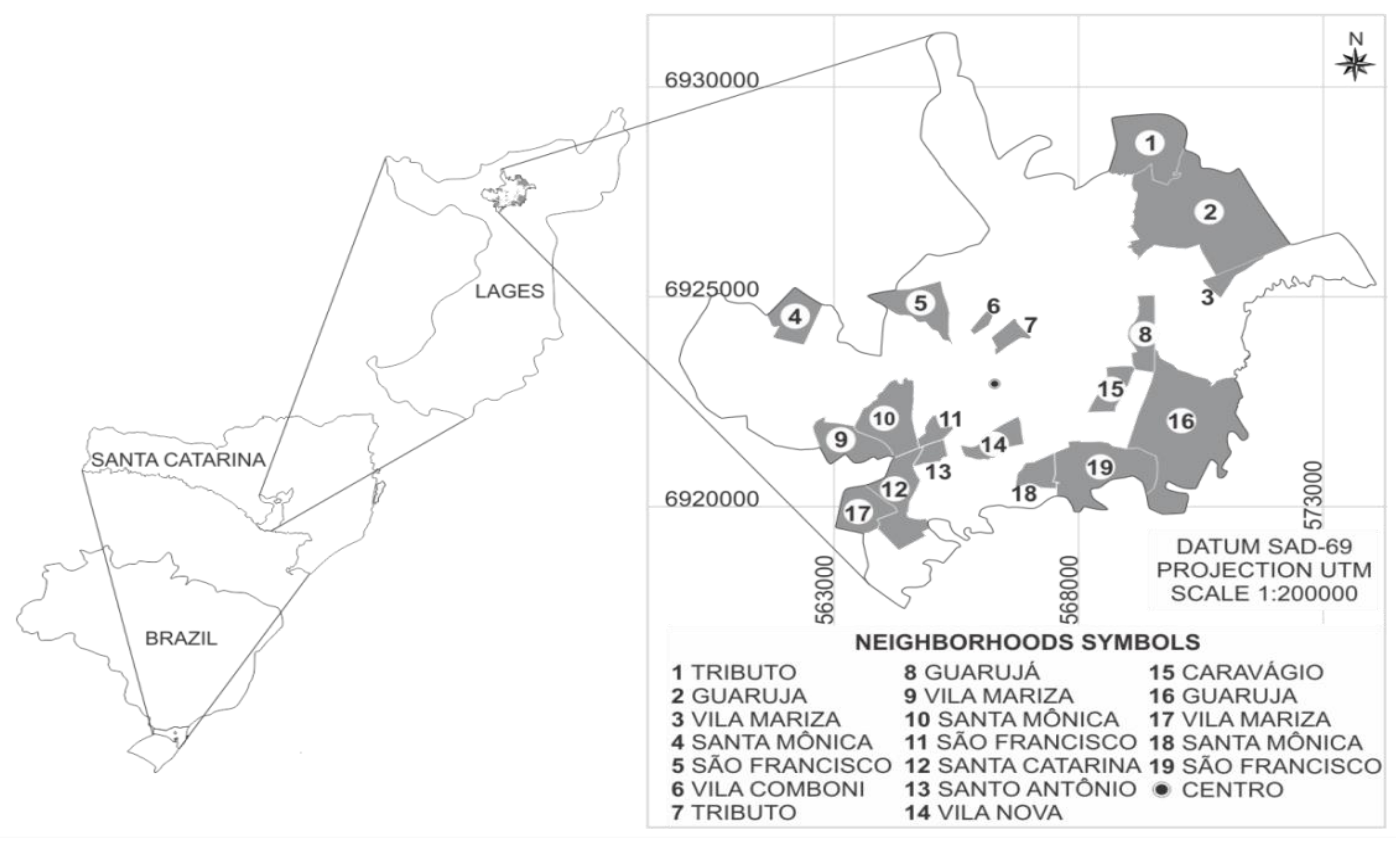

The estimate of T. Canis infected dogs worldwide is $15.2 \%$, ranging from zero to $93 \%$ depending on the evaluated area. In Brazil, the prevalence varies mainly according to the type of study (free-ranging urban dogs, pets and dogs from veterinary clinics, shelters or Zoonosis Control Centers), animal age, season and other variables (QUEIROZ \& CHIEFFI, 2005). All the children evaluated in this study owned dogs at home. According to Carvalho \& Rocha (2011), possessing a dog at home is a risk factor for a positive immune response against T. canis. Damian et al. (2007), demonstrated that home contact with dogs and puppies positively associates to the presence of anti-
Toxocara antibodies in 100 people from 34 sampled families in Amazon.

Positive results for anti-Toxocara IgG were $15.85 \%$ (13/82). Carvalho \& Rocha (2011) informed that the serological prevalence of human toxocariasis can vary from $7 \%$ to $54.8 \%$. Campos Júnior et al. (2003) demonstrated that $21.8 \%$ of samples collected from a public hospital located in Brasília presented T. canis infection, while only 3\% infected samples were found from middle-class private laboratories. A study demonstrated that $32 \%(386 / 1,119)$ of tested children in Paraná presented anti-Toxocara spp. antibodies (MARCHIORO et al. 2011), while in the Brazilian Northeast urban area, the serological prevalence for 1309 children, 
between 4 and 11 years old, was $48.4 \%$ (MENDONÇA et al., 2013).

Kayes (1997) claims that socioeconomic status is not an important risk factor for toxocariasis; however, for some authors there is a clear relationship between positive serology and socioeconomic indicators, observing high prevalence in underdeveloped regions with low income and improper sanitary conditions (KANAFANI et al., 2006).

Several authors reported a substantial prevalence in males as compared to females, at the rate of 1.5 to 2.3 (CARVALHO \& ROCHA, 2011). Accordingly, our study showed $61.54 \%$ positivity for boys as compared to $38.46 \%$ for girls.

Regarding the age of infected children, there is no consensus as previously reported by DESPOMMIER (2003). However, in developed countries, the prevalence was larger in children up to seven years old. For Machado \& Achkar (2003), infections are sporadic and occur worldwide, affecting mainly children under the age of 10, especially children between one and four years old; while positivity in Brazil varied from one to 14 years old (AGUIAR-SANTOS et al., 2004). In Rio Grande do Sul, toxocariasis prevalence occurred more often between eight months to seven years of age (SABROSA \& SOUZA, 2001). On the other hand, in Paraná, the serological prevalence of antiToxocara IgG occurred in children below five years of age (MARCHIORO et al. 2011). The same result was observed for native children in Rio Grande do Sul (PEDROSO et al., 2015). In other studies in Brazil, the most prevalent age was over five years old (ALDERETE et al., 2003).

About the presence and viability of T. canis larvae and eggs in the environment, 1602 soil samples were processed, 504 from central parks and 1098 from peripheral parks, located in seven different neighborhoods of Lages (SC). The parasitological analyses detected Toxocara spp. eggs in $0.75 \%$ of samples, which were distributed as follows: $0.44 \%$ in spring, $0.25 \%$ in summer and $0.06 \%$ in autumn, with no statistical difference among seasons (QUADROS et al., 2014). Earlier studies demonstrated that in summer, dogs presented a greater extent of Ancylostoma spp. infection, revealing a significant difference among seasons (QUADROS et al., 2014). For Naumova et al. (2007), ecological alterations like climate change may influence the emergence and proliferation of parasitic diseases in dogs and may reflect in human parasite 
infections.

In relation to the complete blood count, eosinophilia in children positive for anti-T. canis $\mathrm{IgG}$ was considered within the standard parameters or discreetly elevated. Although eosinophilia is increased in the migration of larvae in tissues, and it may also be altered due to a load of migrating larvae, hypersensitivity reactions, and immune state (PEDROSO et al., 2015).

For Machioro et al. (2011), the eosinophil productions are influenced by the type of helminth, some parasites, location in the host and time of infection. Higa et al. (1990), reported that the eosinophil peak is at 14 days after infection. There are many studies demonstrating that eosinophilia is variable relative to the infection, but may be absent in cases of OLM (CARVALHO \& ROCHA, 2011). ELISA diagnosis method was used in this study, as previously described (DUARTE et al., 2006). Indeed, the test presented $78.3 \%$ sensibility and $92.3 \%$ specificity. On the other hand, Pedroso et al. (2015) reported 45\% sensibility for Ocular Larva Migrans (OLM) detection using the ELISA method.

\section{Conclusion}

Although epidemiological data in children oscillates, it is extremely important to study the parasitosis epidemiological data in different regions of Brazil, since once that cities harbor a lot of dogs in the streets, parks and even trafficking through the peripheral schools.

However, these results serve as a reminder that the population must have a responsible behavior in possessing animals and that public politics must begin to plan an efficient control of urban dogs in the cities to avoid and mitigate diseases like visceral larva migrans, among others.

\section{Acknowledgments}

We thank Biomedical Prof. Paulo Henrique Exterchoter Weiss (in memoriam).

\section{References}

1. AGUIAR-SANTOS A.M.; ANDRADE, L.D.; MEDEIROS, Z.; CHIEFFI, P.P.; LESCANO, S.Z.; PEREZ, E. P. Human toxocariasis: frequency of anti-Toxocara antibodies in children and adolescents from an outpatient clinic for lymphatic filariasis in Recife, Northeast Brazil. Revista do Instituto de Medicina Tropical de São Paulo, v. 46, n.2, p. 81-5, 2004.

2. ALDERETE, J.M.; JACO, A.P.; FOMIN, A.B.; CHIEFFI, P. P. Prevalence of Toxocara infection in school children from the Butantã region, São Paulo, Brazil. Memórias do Instituto Oswaldo Cruz, v. 98, n. 5, p. 593-7, 2003.

3.ALTCHEH, J.; NALLAR, M.; CONCA, M.; BIANCARDI, M.; FREILIJ, H. Toxocariasis: clinical and laboratory features in 54 patients. Anales de Pediatría (Barcelona), v. 58, n.5, p. 425-31, 2003.

4.ALVES, M.C.G.P.; MATOS, M.R.; REICHMANN, M.L.; DOMINGUEZ, M.H. Dimensionamento da população de cães e gatos 
do interior de São Paulo. Revista de Saúde Pública, v. 39, n. 6, p. 891-897, 2005.

5. BÄCHLI, H.; MINET, J.C.; GRATZL, O. Cerebral toxocariasis: a possible cause of epileptic seizure in children. Child's Nervous System, v. 20, n.7, p. 468-472, 2004.

6. BASS, J.L.; MEHTA, K.A.; GLICKMAN, L.T.; BLOCKER, R.; EPPES, B. M. Asymptomatic toxocariasis in children. A prospective study and treatment trial. Clinical Pediatrics, v. 26, n.9, p.441-446, 1987.

7. CAMPOS JÚNIOR, D.; ELEFANT, G.R.; SILVA, E.O.M.; GANDOLFI, L.; JACOB, C.M.A.; TOFETI, A., PRATESI, R. Frequency of seropositivy to Toxocara canis in children of different socioeconomic strata. Revista da Sociedade Brasileira de Medicina Tropical, v.36, n. 4, p. 509-13, 2003.

8. CARVALHO, E.A.A. \& ROCHA, R.L. Toxocaríase: larva migrans visceral em crianças e adolescentes. Journal of Pediatrics, v. 87, n. 2, p.100-110, 2011.

9. COELHO, L.M.P.S. Toxocara spp. Eggs in Public Squares of Sorocaba, São Paulo State, Brazil. Revista do Instituto de Medicina Tropical de São Paulo, v.43, n.4, p.189-191, 2001.

10. DAMIAN, M.M.; MARTINS, M.; SARDINHA, J.F.; CHAVES, A.; TAVARES, A.M. Frequência de anticorpo anti-Toxocara canis em comunidades do rio Uatumã, no estado do Amazonas. Revista da Sociedade Brasileira de Medicina Tropical, v. 40, n. 6, p. 661-664, 2007.

11. DESPOMMIER, D. Toxocariasis: clinical aspects, epidemiology, medical ecology, and molecular aspects. Clinical Microbiology Reviews, v. 16, n. 2, p. 265-72, 2003.

12. DUARTE, M.C.; SCHMIDT, L.P.C.; SALLES, A. M. Larva Migrans Visceral: Relato de dois casos. Revista Médica de Minas Gerais, v. 16, supl. 4, p. 229-32, 2006.
13. GRAEFF- TEIXEIRA, C.; DA SILVA, A.C.A.; YOSHIMURA, K. Update on eosinophilic meningoencephalitis and its clinical relevance. Clinical Microbiology Reviews, v. 22, n.2, p. 322-348, 2009.

14. GUIMARÃES, A.M.; GABELLINI, E.; ALVES, L.; REZENDE, G.F.; RODRIGUES, M.C. Ovos de Toxocara spp. e larvas de Ancylostoma spp. em praça pública de Lavras, MG. Revista de Saúde Pública, v.39, n.2, p. 293-295, 2005.

15. HIGA, A.; MARUYMA, H.; ABE, T.; OWHASHI, M.; NAWA, Y. Effects of Toxocara canis infection hemopoietic stem cells and hemopoietc factors in mice. International Archives of Allergy and Applied Immunology, v. 91, n.3, p. 239-243, 1990.

16. KANAFANI, Z.A.; SKOURY, A.; ARAJ, G.F.; EL-KHORY, M.; SAWAYA, R.A.; ATWEH, S.F.; KANJ, S.S. Seroprevalence of toxocariasis in Lebanon: a pilot study. Parasitology, v. 132, n. 5, p. 635-9, 2006.

17. KAYES, S.G. Human toxocariasis and the visceral larva migrans syndrome: correlative immunopathology. Chemical Immunology, v.66, p. 99-124, 1997.

18. LIM, J.H. Food borne eosinophilia due to visceral larva migrans: a disease abandoned. Journal of Korean Medical Science, v.27, n.1, p.1-2, 2012.

19. MACHADO, A.B. \& ACHKAR, M.E. Larva Migrans Visceral: Relato de Caso. Anais Brasileiros de Dermatologia, v.78, n.2, p. 215219, 2003.

20. MARCHIORO, A., COLLI, C.; MATTIA, S.; PALUDO, M.; MELO, G.; ADAMI, C.M.; PELLOSO, S.M.; GUILHERME, A.L. Avaliação eosinofílica e soropositividade para anticorpos IgG anti- Toxocara em crianças atendidas pelo Sistema Único de Saúde. Revista Paulista de Pediatria, v. 29, n.1, p.80-84, 2011. 
21. MENDONÇA, L.R.; FIGUEIREDO, C.A.; ESQUIVEL, R.; FIACCONE, R.L.; PONTESDE-CARVALHO, L.; COOPER, P.; BARRETO, M.L.; ALCÂNTARA-NEVES, N.M. Seroprevalence and risk factors for Toxocara infection in children from an urban large setting in Northeast Brazil. Acta Tropica, v.128, p. 9095, 2013.

22. MOREIRA-SILVA, S.F.; RODRIGUES, M.G.; PIMENTA, J.L.; GOMES, C.P.; FREIRE, L.H.; PEREIRA, F.E.L. Toxocariasis of the central nervous system: with report two cases. Revista do Instituto de Medicina Tropical de São Paulo, v.37, n.2, p. 169-174, 2004.

\section{MOTTA, V.T. Bioquímica Clínica para o}

Laboratório: Princípios e Interpretações. 5 ed. Rio de Janeiro: Medbook, 2009.

24. MORII, K.; ODA, T.; SATOH, H.; KIMURA, Y.; AOYAMA, Y.; HIRAMATSU, Y.; OKUSHIN, H.; UESAKA, K.; NAKAMURA, S. Toxocara canis-associated visceral larva migrans of the liver. International Journal of Infectious Disease, v.30, p.148-149, 2015.

25. NAUMOVA, E N.; JAGAI, J.S.; MATYAS, B.; DEMARIA, J.R.; MACNEILL, I.B.; GRIFFITHS, J. K. Seasonality in six enterically transmitted diseases and ambient temperature. Epidemiology and Infection, v.135, n.2, p.281292. 2007.

26. PAWLOWSKI, Z. Toxocariasis in humans: clinical expression and treatment dilemma. Journal of Helminthology, v.75, n.4, p. 299305, 2001.

27. PEDROSO, D.; COMPARSI, B.; MROGINSKI, W.; WALCHER, D.L.; NOVICKI, A.; BERNE, M.E.A. Avaliação soroepidemiológica da infecção por Toxocara spp. em crianças indígenas. Arquivos de Ciência e Saúde, v.22, n.2, p. 51-56, 2015.

28. PERUCA, L.C.B., LANGONI, H.; LUCHEIS, S.B. Larva migrans visceral e cutânea como zoonoses: revisão de literatura. Veterinária e Zootecnia, v.16, n.4, p. 601-616, 2009.
29. QUADROS, R.M.; LIZ, F.R.; MARQUES, S.M.T. Ocorrência de ovos de Toxocara spp. em solos de praças públicas de Lages, Santa Catarina. ARS Veterinária, v.30, n.2, p.109114, 2014.

30. QUADROS, R.M.; RONCONI, F.; MARQUES, S.M.T.; WEISS, P.H.E.; ORIDES, M.S. Ancylostoma spp. em cães de rua de Lages, Santa Catarina: variáveis epidemiológicas e coinfecção parasitária. PUBVET, v.8, n.19, p.1- 12, 2014.

31. QUEIROZ, M. L. \& CHIEFFI, P. P. Síndrome de Larva migrans visceral e Toxocara canis. Arquivos Médicos dos Hospitais e da Faculdade de Ciências Médicas da Santa Casa de São Paulo, v.50, n.3, p.117-120, 2005.

32. SABROSA, N.A. \& SOUZA, E.C. Nematode infections of the eye: toxocariasis an diffuse unilateral subacute neuroretinitis. Current Opinion in Ophthalmology, v.12, n.6, p.450-454, 2001.

33. SANTARÉM, V.A.; RUBINSKYELEFANT, G.; CHESINE, P.A.F.; LELI, F.N.C. Toxocaríases Canina e Humana. Veterinária e Zoootecnia, v.12, n.3, p.437-447, 2009.

34. SCAINI, C.J.; TOLEDO, R.N.; LOVATEL, R.; DIONELLO, M.A.; GATTI, F.A.; SUSIN, L.; IGNORINI, V.R.M. Environment contamination by helminth eggs and larvae in dog feces from central area of Cassino Beach, Rio Grande do Sul. Revista da Sociedade Brasileira de Medicina Tropical, v.36, n.5, p.617-619, 2003.

35. VON SÖHSTEN, A.L. \& SILVA, A.V. Toxocaríase humana: risco de infecção alimentar? Veterinária e Zootecnia, v.22, n.4, p. 501-512, 2015. 